\title{
Cardiology
}

\section{Association of $A C E$ Gene Polymorphism with Hypertension and Metabolic Risk Factors among Indigenous People of the Northern Territory of Yakutia}

\author{
Sargylana I. Sofronova, PhD*; Maria P. Kirillina, PhD; Vyacheslav M. Nikolaev, PhD; \\ Sardaana K. Kononova; Oksana G. Sidorova; Anna N. Romanova \\ Yakut Science Center of Complex Medical Problems \\ Yakutsk, the Republic of Sakha (Yakutia), Russia
}

\begin{abstract}
The research objective was to study the association of the $A C E$ gene I/D polymorphism with essential hypertension (EH) and metabolic risk factors among indigenous people of the northern territory of Yakutia. The obtained data show that representatives of indigenous people of the North of Yakutia with the $A C E$ ID genotype are characterized with high levels of systolic blood pressure. The carriage of DD genotype in EH patients was associated with a high frequency of hypercholesterolemia and hyper-LDL cholesterolemia. The carriage of ID genotype in EH patients, compared to subjects without EH, was characterized by higher blood levels of TC, LDL-C, TG, and FPG and associated with a high frequency of obesity. Thus, the $A C E$ I/D polymorphism was found to be associated with metabolic risk factors in indigenous EH patients of the North of Yakutia. (International Journal of Biomedicine. 2019;9(2):102-105.)
\end{abstract}

Key Words: essential hypertension $\bullet A C E$ gene $\bullet$ indigenous people $\bullet$ risk factors

\section{Abbreviations}

ACE, angiotensin-converting enzyme; AO, abdominal obesity; EH, essential hypertension; FPG, fasting plasma glucose; HDL-C, high-density lipoprotein cholesterol; LDL-C, low-density lipoprotein cholesterol; OGTT, oral glucose tolerance test; RAS, renin-angiotensin system; SBP, systolic blood pressure; WS, waist circumference.

\section{Introduction}

Hypertension is one of the main risk factors worldwide for cardiovascular disease and the main reason for a high mortality rate among the adult population..$^{(1,2)}$ Essential hypertension (EH), the most common form of hypertension, ${ }^{(3)}$ is defined as an elevation in blood pressure of unknown cause, which increases the risks for cerebral, cardiac, and renal complications. ${ }^{(4)} \mathrm{EH}$ is considered a multifactorial disease. ${ }^{(5)}$ From a genetic perspective, many single nucleotide polymorphisms (SNPs), genes and epigenetic factors are associated with EH. ${ }^{(6)}$ Currently, increasing attention is being paid to RAS genes in the development of EH, and the value of

*Corresponding author: Sargylana I. Sofronova, PhD. Yakut Science Center of Complex Medical Problems. Yakutsk, the Republic of Sakha (Yakutia),Russia.E-mail: sara2208@mail.ru
$A C E$ gene $\mathrm{I} / \mathrm{D}$ polymorphism has been investigated in many studies $^{(7-9)} \mathrm{A}$ strong association between the DD genotype and the D allele with $\mathrm{EH}$, abdominal obesity and coronary artery disease was revealed in a number of studies. ${ }^{(10-12)}$ Grigor'eva found a significant association between $A C E$ gene polymorphism and the risk of myocardial infarction in Yakut men. ${ }^{(13)}$

The research objective was to study the association of $A C E$ gene polymorphism with hypertension and metabolic risk factors among indigenous people of the northern territory of Yakutia.

\section{Materials and Methods}

This study was done to determine the clinicoepidemiological aspects of $\mathrm{EH}$ in the remote districts in the North of Yakutia (Kolymskoye and Andryushkino rural 
localities of the Nizhnekolymsky District, Topolinoe rural locality of the Tomponsky District, Nelemnoye rural locality of the Verkhnekolymsky District). A total of 348 indigenous people of Yakutia (Evens, Chukchi, Yukaghirs, Yakuts) (225 women and 123 men) were examined. The patient sample consisted of adults aged between 20 and 70 years, with an average age of $45.71 \pm 0.67$ years. All patients were divided into 2 groups. Group 1 consisted of 175 patients (mean age of $53.11 \pm 0.51$ years) with $\mathrm{EH}$; Group 2 (control group) included 173 people (mean age of $38.88 \pm 0.60$ years) without elevated blood pressure.

The study was approved by the Ethics Committee of the Yakut Science Center of Complex Medical Problems. Written informed consent was obtained from each patient.

A comprehensive clinical examination and laboratory tests included the following procedures:

- Anthopometrical reference data: BMI was calculated using Quetelet's formula (in $\mathrm{kg} / \mathrm{cm}^{2}$ ). Measurement of WC was made at the uppermost lateral border of the ilium using a tape measure (in $\mathrm{cm}$ )

- Assessment of blood pressure by Korotkov's method.

- Assessment of FPG, OGTT, and blood levels of TG, HDL-C, LDL-C.

Glucose and lipid metabolism disorders were diagnosed according to the Russian national recommendations (the AllRussian Scientific Society of Cardiologists, 2009) ${ }^{(14)}$ based on the IDF consensus criteria (2006) ${ }^{(15)}$ : TG $\geq 1.7 \mathrm{mmol} / \mathrm{l}$; HDL-C $<1.0 \mathrm{mmol} / 1$ in males and $<1.2 \mathrm{mmol} / 1$ in females; LDL-C $>3.0 \mathrm{mmol} / \mathrm{l} ; \mathrm{FPG}>6.1 \mathrm{mmol} / \mathrm{l}$; IGT $2 \mathrm{Hr}$ PG $\geq 7.8 \mathrm{mmol} / \mathrm{l}$ and $\leq 11 \mathrm{mmol} / 1$. Abdominal obesity (AO) was confirmed at WC $\geq 94 \mathrm{~cm}$ in males and $\geq 80 \mathrm{~cm}$ in females.

The diagnosis of hypertension was based on 2017 ACC/ AHA Guideline for or the Prevention, Detection, Evaluation, and Management of High Blood Pressure in Adults. ${ }^{(16)}$

The insertion/deletion (I/D) polymorphism of the $A C E$ gene was examined by PCR in the laboratory of molecular genetics at Yakut Science Center of Complex Medical Problems. From each patient, $2 \mathrm{ml}$ of peripheral blood were drawn into an EDTA tube. Genomic DNA was isolated from the peripheral blood leukocytes using standard phenolchloroform extraction technique (Maniatis et al., 1982) Genotyping was carried out with the allele specific primers method.

Reactions were performed with 10 pmol of each primer:

F: 5'-CTG GAG ACC ACT CCC ATC CTT TCT-3' R: 5'-GAT GTG GCC ATC ACA TTC GTC AGA T-3'.
PCR products were analyzed on $2 \%$ agarose gels after staining with ethidium bromide and were visualized using a UV transilluminator. Two alleles were identified: a 490bp fragment I (with the insertion) and a 190-bp fragment D (without the insertion). In heterozygous samples, two bands (490 and $190 \mathrm{bp}$ ) were detected. To avoid mistyping of heterozygotes (ID) DNA samples identified as a DD genotype were subsequently amplified with second set of primers designed for the insertion specific allele.

Statistical analysis was performed using SPSS (version 17.0). Baseline characteristics were summarized as frequencies and percentages for categorical variables and as mean \pm SEM for continuous variables. Student's unpaired and paired t-tests were used to compare two groups for data with normal distribution. Odds ratios (OR) and 95\% confidence intervals (CI) were calculated. Multiple comparisons were performed with one-way ANOVA and post-hoc Tukey HSD test. Deviation from Hardy-Weinberg equilibrium and differences in allele distributions between the two groups were assessed by $\chi 2$ - test with 1 degree of freedom (df). A probability value of $P<0.05$ was considered statistically significant.

\section{Results and Discussion}

In the general population, the $A C E$ II, ID, and DD genotype frequencies were $19.5 \%(\mathrm{n}=68), 65.2 \%(\mathrm{n}=227)$, and $15.2 \%(n=227)$. We did not find statistically significant differences in the frequency distribution of $A C E$ I/D alleles and genotypes between the group of patients and control group (Table 1). The distribution of the genotype frequency was not in HWE for patients $\left(\chi^{2}=19.17, \mathrm{p}<0.05\right)$ and for controls $\left(\chi^{2}=13.95, \mathrm{p}<0.05\right)$. The occurrence of the departure from HWE in controls is probably due to population substructure. We further used the three types of genetic models to test the association between the $A C E \mathrm{I} / \mathrm{D}$ polymorphism and $\mathrm{EH}$; the results are shown in Tables $2 \mathrm{a}-2 \mathrm{c}$. We found no association between the $A C E \mathrm{I} / \mathrm{D}$ polymorphism and $\mathrm{EH}$ in our casecontrol study.

Table $2 a$.

General model of inheritance $(d f=2)$

\begin{tabular}{|c|c|c|c|c|c|c|}
\hline \multirow{2}{*}{ Genotyp } & \multicolumn{2}{|c|}{ Genotype frequencies } & \multirow{2}{*}{$\chi^{2}$} & \multirow{2}{*}{$P$} & \multirow{2}{*}{ OR } & \multirow{2}{*}{$95 \% \mathrm{CI}$} \\
\hline & Patients & Control & & & & \\
\hline II & 0.200 & 0.191 & \multirow{3}{*}{0.63} & \multirow{3}{*}{0.73} & 1.06 & $0.62-1.80$ \\
\hline ID & 0.663 & 0.642 & & & 1.10 & $0.71-1.71$ \\
\hline $\mathrm{DD}$ & 0.137 & 0.168 & & & 0.79 & $0.44-1.42$ \\
\hline
\end{tabular}

Table 1.

Frequencies of the genotypes and alleles of the ACE I/D polymorphism and deviations from HWE $(d f=1)$

\begin{tabular}{|c|c|c|c|c|c|c|c|c|c|c|c|}
\hline \multirow{2}{*}{ Genotype } & \multirow{2}{*}{ Patients } & \multirow{2}{*}{ HWE } & \multirow{2}{*}{$\chi^{2}$} & \multirow{2}{*}{$P$} & \multirow{2}{*}{ Control } & \multirow{2}{*}{ HWE } & \multirow{2}{*}{$\chi^{2}$} & \multirow{2}{*}{$P$} & \multirow{2}{*}{ Allele } & \multicolumn{2}{|c|}{ Allele frequencies } \\
\hline & & & & & & & & & & Patients & Control \\
\hline II & 0.200 & 0.282 & \multirow{3}{*}{19.17} & \multirow{3}{*}{$1.0 \mathrm{E}-5$} & 0.191 & 0.262 & \multirow{3}{*}{13.95} & \multirow{3}{*}{0.0002} & I & 0.531 & 0.512 \\
\hline ID & 0.663 & 0.498 & & & 0.642 & 0.500 & & & $\mathrm{D}$ & 0.469 & 0.488 \\
\hline $\mathrm{DD}$ & 0.137 & 0.220 & & & 0.169 & 0.239 & & & & & \\
\hline
\end{tabular}


Table $2 b$.

Dominant model of inheritance $(d f=1)$

\begin{tabular}{|c|c|c|c|c|c|c|}
\hline \multirow{2}{*}{ Genotype } & \multicolumn{2}{|c|}{ Genotype frequencies } & \multirow{2}{*}{$\chi^{2}$} & \multirow{2}{*}{$P$} & OR & \multirow{2}{*}{$95 \%$ CI } \\
\cline { 2 - 3 } & Patients & Control & & & & \\
\hline II+ID & 0.863 & 0.832 & \multirow{2}{*}{0.63} & \multirow{2}{*}{0.43} & 1.27 & $0.70-2.28$ \\
\hline DD & 0.137 & 0.168 & & & 0.79 & $0.44-1.42$ \\
\hline
\end{tabular}

Table 2c.

Recessive model of inheritance $(d f=1)$

\begin{tabular}{|c|c|c|c|c|c|c|}
\hline \multirow{2}{*}{ Genotype } & \multicolumn{2}{|c|}{ Genotype frequencies } & \multirow{2}{*}{$\chi^{2}$} & \multirow{2}{*}{$P$} & \multirow{2}{*}{ OR } & \multirow{2}{*}{$95 \% \mathrm{CI}$} \\
\cline { 2 - 3 } & Patients & Control & & & & \\
\hline II & 0.200 & 0.191 & \multirow{2}{*}{0.05} & \multirow{2}{*}{0.83} & 1.06 & $0.62-1.80$ \\
\hline ID+DD & 0.800 & 0.809 & & & 0.94 & $0.55-1.60$ \\
\hline
\end{tabular}

In the general population $(n=348)$, we did not find significant differences in average values of TG, LDL-C, and HDL-C depending on the carriage of genotypes of the $A C E$ I/D polymorphism. The frequency of hypercholesterolemia was $51.5 \%$ in carriers of II homozygous genotype, $42.7 \%$ in carriers of ID heterozygous genotype, and $49.1 \%$ in carriers of DD heterozygous genotype $(P>0.05)$. Hyper-LDL cholesterolemia was found in $64.2 \%$ of DD homozygotes, $54.4 \%$ of II homozygotes, and $54.6 \%$ of ID heterozygotes $(P>0.05)$. Hypo-HDL cholesterolemia was found in $33.8 \%$ of II homozygotes, $34.8 \%$ of ID heterozygotes, and $35.8 \%$ of DD homozygotes $(P>0.05)$. The frequency of hyperglycemia was as follows: ID carriers - $6.6 \%$, II carriers - $2.9 \%$, and DD carriers $-3.8 \%$.

In Croup 1 (patients with EH), the average level of SBP in ID carriers, II carriers and DD carriers was $144.2 \pm 1.2 \mathrm{mmHg}$, $136.6 \pm 2.8 \mathrm{mmHg}$ and $138.8 \pm 2.1 \mathrm{mmHg}$, respectively, $P=0.0072$. Table 3 presents the relationship between $A C E$ genotype carriage and parameters of lipid and glucose metabolism in two groups. In ID carriers, the blood levels of TC, LDL-C, TG, and FPG were significantly higher in Group 1 than in Group 2. In II carriers, the blood level of TG was significantly higher in Group 1 than in Group 2.

We found a high frequency of hyper-LDL cholesterolemia in DD carriers of Group $1(70.8 \%)$ compared to Group 2 (58.4\%) $(P=0.015)$. In DD carriers, the frequency of hypercholesterolemia was also significantly higher in Group 1 than in Group 2 (66.8\% versus $34.7 \%, P=0.000$ )
In the general population, the frequency of $\mathrm{AO}$ in ID carriers, II carriers and DD carriers was as follows: $59.9 \%$, $55.9 \%$, and $50.9 \%$, respectively, $P>0.05$. The average level of WC in ID carriers, II carriers and DD carriers was $89.61 \pm 0.65$ $\mathrm{cm}, 86.46 \pm 1.49 \mathrm{~cm}$, and $86.75 \pm 1.52 \mathrm{~cm}$, respectively, $P=0.0391$.

In Group 1, the average level of WC in ID carriers, II carriers and DD carriers was $96.23 \pm 0.89 \mathrm{~cm}, 91.43 \pm 1.99 \mathrm{~cm}$, and $92.63 \pm 1.27 \mathrm{~cm}(P=0.0205)$, respectively. The frequency of AO was as follows: ID carriers $-84.5 \%$, II carriers $-71.4 \%$, and DD carriers $-66.7 \%(P>0.05)$. AO frequency in ID carriers vs. DD carriers was significantly higher $(P<0.05)$.

In Group 2 the average level of WC in ID carriers, II carriers and DD carriers was $82.68 \pm 0.68 \mathrm{~cm}, 81.18 \pm 1.85 \mathrm{~cm}$, and $81.90 \pm 1.21 \mathrm{~cm}(P>0.05)$. The frequency of $\mathrm{AO}$ was as follows: ID carriers $-34.2 \%$, II carriers $-39.4 \%$, and DD carriers $-37.9 \%(P>0.05)$

\section{Conclusion}

The obtained data show that representatives of indigenous people of the North of Yakutia with the $A C E$ ID genotype are characterized with high levels of SBD. The carriage of DD genotype in EH patients is associated with a high frequency of hypercholesterolemia and hyper-LDL cholesterolemia. The carriage of ID genotype in EH patients, compared to subjects without $\mathrm{EH}$, is characterized by higher blood levels of TC, LDL-C, TG, and FPG and associated with a high frequency of AO. A number of studies have also found a high frequency of metabolic syndrome in ID carriers. ${ }^{(17-20)}$ Thus, the $A C E \mathrm{I} / \mathrm{D}$ polymorphism was found to be associated with metabolic risk factors in indigenous $\mathrm{EH}$ patients of the North of Yakutia.

\section{Competing Interests}

The authors declare that they have no competing interests.

\section{Sources of Funding}

The study was carried out within the framework of the project "Contribution of metabolic syndrome to the development of coronary artery atherosclerosis in residents of Yakutia" and R\&D "Development of new technologies for the treatment and risk prediction of hypertension and stroke in the Republic of Sakha (Yakutia)" (State Contract No. 1133).

\section{Table 3.}

Mean concentrations of lipid spectrum and glucose among hypertensive patients and persons without hypertension

\begin{tabular}{|l|c|c|c|c|c|c|c|c|c|}
\hline \multirow{2}{*}{$\begin{array}{c}\text { Blood } \\
\text { parameters }\end{array}$} & \multicolumn{3}{|c|}{ Genotype II } & \multicolumn{3}{c|}{ Genotype ID } & \multicolumn{3}{c|}{ Genotype DD } \\
\cline { 2 - 9 } & Group 1 & $P$ & Group 2 & Group 1 & $P$ & Group 2 & Group 1 & $P$ & Group 2 \\
\hline TC & $5.05 \pm 0.14$ & $>0.05$ & $4.68 \pm 0.16$ & $5.15 \pm 0.09$ & $<0.01$ & $4.79 \pm 0.07$ & $5.13 \pm 0.16$ & $>0.05$ & $4.71 \pm 0.16$ \\
\hline LDL-C & $3.24 \pm 0.13$ & $>0.05$ & $2.88 \pm 0.13$ & $3.32 \pm 0.08$ & $<0.01$ & $3.05 \pm 0.06$ & $3.32 \pm 0.14$ & $>0.05$ & $3.07 \pm 0.12$ \\
\hline HDL-C & $1.26 \pm 0.05$ & $>0.05$ & $1.37 \pm 0.06$ & $1.26 \pm 0.03$ & $>0.05$ & $1.33 \pm 0.03$ & $1.28 \pm 0.06$ & $>0.05$ & $1.14 \pm 0.05$ \\
\hline TG & $1.21 \pm 0.09$ & $<0.02$ & $0.92 \pm 0.07$ & $1.21 \pm 0.05$ & 0.000 & $0.91 \pm 0.03$ & $1.16 \pm 0.10$ & $>0.05$ & $1.07 \pm 0.08$ \\
\hline FPG & $4.48 \pm 0.18$ & $>0.05$ & $4.41 \pm 0.14$ & $5.02 \pm 0.17$ & 0.000 & $4.19 \pm 0.08$ & $4.48 \pm 0.27$ & $>0.05$ & $4.25 \pm 0.14$ \\
\hline
\end{tabular}




\section{References}

1. Appel LJ; American Society of Hypertension Writing Group, Giles TD, Black HR, Izzo JL Jr, Materson BJ, Oparil S, Weber MA. ASH Position Paper: Dietary approaches to lower blood pressure. J Clin Hypertens (Greenwich). 2009;11(7):358-68. doi: 10.1111/j.1751-7176.2009.00136.x.

2. Oganov RG, Timofeeva TN, Koltunov IE, Konstantinov VV, Balanova YA, Kapustina AV, et al. [Arterial hypertension epidemiology in Russia; the results of 2003-2010 federal monitoring]. Cardiovascular Therapy and Prevention. 2011;10(1):9-13. [Article in Russian].

3. Oparil S1, Zaman MA, Calhoun DA. Pathogenesis of hypertension. Ann Intern Med. 2003;139(9):761-76.

4. Messerli FH1, Williams B, Ritz E. Essential hypertension. Lancet. 2007 ;370(9587):591-603.

5. Nakayama T1. [Genetic factors of hypertension]. Rinsho Byori. 2013;61(2):144-9. [Article in Japanese]

6. Natekar A, Olds RL, Lau MW, Min K, Imoto K, Slavin TP. Elevated blood pressure: Our family's fault? The genetics of essential hypertension. World J Cardiol. 2014;6(5):327-37. doi: 10.4330/wjc.v6.i5.327.

7. Fox CS1, Heard-Costa NL, Vasan RS, Murabito JM, D'Agostino RB Sr, Atwood LD; Framingham Heart Study. Genomewide linkage analysis of weight change in the Framingham Heart Study.J Clin Endocrinol Metab. 2005;90(6):3197-201.

8. Penesova A, Cizmarova E, Kvetnansky R, Koska J, Sedlakova B, Krizanova O. Insertion/deletion polymorphism on ACE gene is associated with endothelial dysfunction in young patients with hypertension. Horm Metab Res. 2006;38(9):592-7.

9. Zivko M, Kusec R, Galesić K. Impact of angiotensinconverting enzyme gene polymorphism on proteinuria and arterial hypertension. Coll Antropol. 2013;37(3):765-70.

10. Irijanto $F$, Rahajeng $H$, Kamajaya $S$, Sja'bani $M$, Sadewa A, Tomino Y. High D Allele Frequency of ACE I/D Gene Polymorphism in Familial Hypertension in Javanese Indonesian. Juntendo Medical Journal, 2012. 58(3):224-230.

11. Kotlovsky MYu, Kotlovskaya OS, Osedko OYa, Kirichenko DS, Pokrovsky AA, Osedko AV, et al. Gene polymorphism of the angiotensin-converting enzyme in people with hypertension and chronic IHD. Fundamentalnye issledovania. 2011;11-1:49-52.

12. Strazzullo P, Iacone R, Iacoviello L, Russo O, Barba G, Russo P, et al.; Olivetti Prospective Heart Study. Genetic variation in the renin-angiotensin system and abdominal adiposity in men: the Olivetti Prospective Heart Study. Ann Intern Med. 2003;138(1):17-23.

13. Grigor'eva, L.V. Molecular-genetic study of myocardial infarction in the Yakut population. PhD Thesis. Ufa; 2006.[In Russian].

14. Metabolic syndrome diagnostics and treatment. Compilation of national recommendations. Moscow: SiliceaPoligraf Publishers; 2009:106-143. [In Russian].

15. IDF Consensus Worldwide Definition of the Metabolic Syndrome, 2006. Available from: https://www.idf.org/elibrary/consensus-statements/60-idfconsensus-worldwidedefinitionof-the-metabolic-syndrome

16. Whelton PK, Carey RM, Aronow WS, Casey DE Jr, Collins KJ, Dennison Himmelfarb C, et al. 2017 ACC/AHA/ AAPA/ABC/ACPM/AGS/APhA/ASH/ASPC/NMA/PCNA Guideline for the Prevention, Detection, Evaluation, and Management of High Blood Pressure in Adults: A Report of the American College of Cardiology/American Heart Association Task Force on Clinical Practice Guidelines. J Am Coll Cardiol. 2018;71(19):e127-e248. doi: 10.1016/j.jacc.2017.11.006.

17. Bhavani BA, Padma T, Sastry BK, Krishna Reddy N, Nausheenm K. The Insertion I/ Deletion D polymorphism of Angiotensin- Converting Enzyme (ACE) Gene Increase the Susceptibility to Hypertension and / or Diabetes. Int J Hum Genet. 2017;5(4):247-252.

18. Randhawa NK, Kumar A, Matharoo K, Bhanwer AS. Association Study of Angiotensin-Converting Enzyme Ins/ Del Polymorphism with Hypertension in Punjabi Population. Int J Hum Genet. 2006;6:317-321. D

19. Sameera AS, Syeeda N, Takc S, Bashird S, Nissara S, Siddiqi M. ACE I/D Polymorphism in Hypertensive Patients of Kashmiri Population. Cardiology Research. 2010;1(1):1-7. 20. Sun F, He N, Zhang K, Wu N, Zhao J, Qiu C. Association of ACE gene A2350G and I/D polymorphisms with essential hypertension in the northernmost province of China. Clin Exp Hypertens. 2018;40(1):32-38. doi: 10.1080/10641963.2017.1291659. 